Państwo-Prawo-Administracja

$1(1) / 2016$

ISSN 2451-1676

DOI: http://dx.doi.org/10.21784/PPA.2016.001

JUDYTA BIELANOWSKA

Uniwersytet Mikołaja Kopernika w Toruniu

\title{
Firmy ochroniarskie i detektywistyczne w Polsce jako podmioty prywatyzacji zadań publicznych - szanse i zagrożenia
}

\author{
Security and detective firms in Poland \\ as objects of privatizing public tasks - \\ opportunities and threats
}

\section{Streszczenie:}

Funkcjonowanie firm ochroniarskich i detektywistycznych w Polsce implikuje pytanie o kwestię prywatyzacji zadań publicznych. Jednym z wielu możliwych aspektów rozpatrywania tego zagadnienia jest możliwość powierzania spraw z obszaru bezpieczeństwa wewnętrznego podmiotom niepublicznym. Konsekwencje ich scedowania na firmy ochroniarskie i detektywistyczne bywają rozmaite, $\mathrm{w}$ związku z czym istotne wydaje się rozpatrywanie ich w kategoriach zarówno szans, jak i zagrożeń dla prawidłowego funkcjonowania tej dziedziny polityki publicznej. Doniosłe znaczenie posiada zatem w tym samym stopniu kwestia uregulowań prawnych omawianej problema- 
tyki, co ich implementacja. Nie mniej ważne są również szeroko pojęte społeczne reperkusje zastosowania tych rozwiązań w praktyce.

\begin{abstract}
:
The functioning of security and detective firms in Poland poses a question about the issue of privatization of public tasks. One of the many possible aspects of the treatment of this issue is the possibility of delegating matters in the area of internal security to non-public entities. The consequences of such delegation on security and detecitve firms tend to be different, and therefore it seems important to consider them in terms of both opportunities and threats to the proper functioning of public policy. Great importance has, therefore, to the same extent a matter of legislation discussed issues as their implementation. The question of legislation and its implementation plays therefore a key role. No less important are the social reaction to the broad application of these solutions in practice.
\end{abstract}

Słowa kluczowe: firmy ochroniarskie i detektywistyczne; prywatyzacja zadań publicznych.

Keywords: security and detecitve firms, privatization of public tasks.

\title{
1. Specyfika prywatyzacji zadań z zakresu bezpieczeństwa wewnętrznego
}

Celem niniejszej analizy jest wskazanie na specyfikę prywatyzacji zadań z zakresu bezpieczeństwa wewnętrznego, stanowiącej w szerokim rozumieniu legalne wykonywanie zadań ustawowo przypisanych instytucjom publicznym. Dążąc do uproszczenia, a zarazem skonkretyzowania tego zjawiska, podjęto problematykę funkcjonowania firm ochroniarskich i detektywistycznych w Polsce w kontekście prywatyzacji zadań Policji. Ukazane zostaną zarówno korzyści wnikające z prywatyzacji zadań z zakresu bezpieczeństwa wewnętrznego, a więc dziedziny niezwykle istotnej z punktu widzenia prawidłowego funkcjonowania społeczeństwa w sferze publicznej, jak i zagrożenia mogące zaistnieć na skutek redukcji zadań administracji 
publicznej i scedowania ich na podmioty prywatne. Istotne $\mathrm{w}$ tym kontekście wydaje się pytanie postawione przez Zbigniewa Leońskiego o granice, których prywatyzacja nie powinna przekraczać oraz o to, czy korzystanie z nowych form organizacyjnych rzeczywiście zabezpiecza interesy jednostki lub społeczeństwa, a także nie pozostaje w sprzeczności z poszanowanie praw i wolności jednostki ${ }^{1}$. Aby jednak rozważyć tego rodzaju wątpliwości oraz jednoznacznie rozumieć pojęcie prywatyzacji, a w konsekwencji właściwie identyfikować jej następstwa, należy w pierwszej kolejności ustalić ramy definicyjne tego zjawiska. Według Stanisława Biernata prywatyzację zadań publicznych można rozumieć dwojako. Po pierwsze jest to zmiana cech podmiotu wykonującego zadanie, polegająca na tym, iż miejsce podmiotu prawa publicznego zajmuje podmiot prawa prywatnego cywilnego lub handlowego, a zatem istota zmiany polega tu na tym, iż zadania publiczne przekazywane są podmiotowi prawa prywatnego bądź też wykonujący zadania podmiot zmienia swój dotychczasowy charakter prawny. Po drugie prywatyzacja może być również rozumiana jako zmiana form wykonywania zadań z formy prawa publicznego (administracyjnego) na formę prawa prywatnego oraz zmianie charakteru stosunków na gruncie styczności podmiotów wykonujących zadania publiczne $\mathrm{z}$ obywatelami2. Od prywatyzacji należy jednak wyraźnie odróżnić pojęcie uspołecznienia zadań publicznych, oznaczające wykonywanie zadań publicznych przez organizacje społeczne, a więc poza strukturami organizacyjnymi państwa. Ponadto termin „uspołecznienie” nie zawiera wskazania na zmianę sposobów wykonywania zadań, takich jak ich demokratyzacja lub zwiększenie partycypacji społecznej $\mathrm{w}$ administrowaniu ${ }^{3}$. Cechą dystynktywną

1 Z. Leoński, Funkcje (zadania i kompetencje) realizowane przez podmioty prawa prywatnego (tezy referatu), [w:] Administracja i prawo administracyjne u progu trzeciego tysiąclecia. Materiały konferencji naukowej katedr prawa i postępowania administracyjnego, Łódź 2000, s. 268-269.

2 S. Biernat, Prywatyzacja zadań publicznych. Problematyka prawna, WarszawaKraków 1994, s. 26.

3 Tamże, s. 31. 
obu tych pojęć jest również odpłatność wykonywania zadań administracji publicznej $\mathrm{w}$ przypadku ich prywatyzacji. A zatem usługi świadczone przez firmy ochroniarskie i detektywistyczne niewątpliwie wpisują się w zakres czynności odpłatnych, przebiegających w dziedzinie działalności gospodarczej, w związku z czym uprawnione jest rozpatrywanie szans i zagrożeń wynikających z przejmowania przez te podmioty zadań dotyczących bezpieczeństwa wewnętrznego w kategoriach prywatyzacji.

\section{Regulacje prawne i ich interpretacja}

Problematykę organizacyjno-prawną określającą funkcjonowanie firm ochroniarskich określa ustawa z dnia 22 sierpnia $1997 \mathrm{r}$. o ochronie osób i mienia ${ }^{4}$, jak również ustawa z dnia 20 marca 2009 r. o bezpieczeństwie imprez masowych ${ }^{5}$. Prywatyzacja zadań Policji odnosi się jednak przede wszystkim do wykonywania zadań przez firmy ochroniarskie w oparciu o przepisy o ochronie osób i mienia. Aby dostrzec różnice pomiędzy dawnym a obecnym funkcjonowaniem firm ochroniarskich, warto zwrócić uwagę na kontekst instytucjonalno - prawny, w którym ustawa o ochronie osób i mienia powstawała. Otóż zmiany ogólnospołeczne, zachodzące po 1989 r., oznaczały poważne przeobrażenia w systemie polityczno - ekonomicznym państwa, wyprzedzając wiele uregulowań prawnych. Ostatecznie doszło do zaistnienia poważnej asymetrii między stanem prawnym a potencjałem i zakresem działania firm ochrony, obejmującym: ochronę fizyczną osób i mienia, w tym także konwoje wartości pieniężnych oraz tzw. interwencje, oznaczające reagowanie własnych agencji ochrony na sygnały zagrożenia $\mathrm{z}$ miejsc objętych ochroną; ochronę techniczną, obejmującą zabezpieczenia mechaniczne, nowoczesne systemy alarmowe, elektroniczne, m.in. kontrolę dostępu do

\footnotetext{
Dz.U. z 2005 r. Nr 145, poz. 1221 z późn. zm.

Dz.U. z 2009 r. Nr 62, poz. 504 z późn. zm.
} 
określonych obszarów, sygnalizację napadu, włamania, pożaru łącznie $\mathrm{z}$ całodobowym monitorowaniem sygnałów w utworzonych do tego celu bazach; dziedzinę działalności agencji ochrony, jakimi są usługi detektywistyczne ${ }^{6}$. Usługi, zlecane najczęściej przez osoby fizyczne, rzadziej prawne, obejmowały czynności ustaleniowe, wykrywacze bądź poszukiwawcze, a zatem znajdujące się do tej pory w wyłącznej kompetencji służb policyjnych, natomiast podstawą prawną regulującą taki stan rzeczy pozostawała ustawa z dnia 23 grudnia 1988 r. o działalności gospodarczej. Nie zawierała ona jednak żadnych norm dotyczących sposobu wykonywania koncesji, a w szczególności norm określających uprawnienia pracowników ochrony do stosowania środków przymusu bezpośredniego i użycia broni palnej. Dlatego też w takiej sytuacji przyjmowano, iż posiadają oni te same prawa, którymi dysponuje każdy obywatel. Uprawnienia ta wynikały w szczególności z przepisów kodeksów: karnego, cywilnego i postępowania karnego. W oparciu o tego rodzaju rozproszone przepisy, pozostawiające pewien margines dowolności interpretacyjnej, a tym samym stwarzające pole do daleko idących nadużyć, znamiennych zwłaszcza dla okresu przemian ustrojowych, na szeroką skalę i w bardzo szybkim tempie zaczęły powstawać podmioty gospodarcze świadczące usługi ochrony osób i mienia wzbudzające poważne wątpliwości co do legalności swego działania. Kwestii tej nie rozwiązywała również nowelizacja ustawy o działalności gospodarczej, uchwalona w październiku 1991 r., dająca upoważnienia Radzie Ministrów i Ministrowi Spraw Wewnętrznych do określenia szczegółowych warunków wykonywania usług ochrony osób i mienia, ponieważ delegacja ta nigdy nie została zrealizowana. Dlatego też ówczesna działalność prywatnych firm ochroniarskich wzbudzała podejrzliwość, nieufność i niechęć Policji, a tym samym, na deklaratywnym gruncie współpracy tychże podmiotów, pozostawała w sprzeczności z celem którym powinno być podniesienie stanu bezpieczeństwa i ogranicze-

6 S. Tokarz, Firmy detektywistyczne i ochroniarskie w Polsce, [w:] J. Widacki, J. Czapska (red.), Bezpieczny obywatel - bezpieczne państwo, Lublin 1998, s. 348. 
nie przestępczości Warto wskazać, iż jedną z przyczyn takiego stanu rzeczy były przypadki ewidentnie przestępczej działalności nie tylko pojedynczych ochroniarzy, ale także całych firm ochrony. Tworzeniu firm ochroniarsko - detektywistycznych, mogących stanowić dobry kamuflaż dla działalności grup przestępczych lub działania na ich zlecenie, a nawet współpracy z obcymi służbami specjalnymi, sprzyjał także brak uregulowania działalności detektywistycznej, co nie tylko tworzyło lukę prawną w przepisach, ale także doprowadziło do sytuacji, w której, co prawda, na mocy ustawy o ochronie osób i mienia z 1997 r. sprecyzowano kwestie co do wymogów stawianych pracownikom ochrony osób i mienia, ale nie odniesiono się do pracowników wykonujących usługi detektywistyczne, polegające przede wszystkim na sprawdzaniu wiarygodności aktualnego lub potencjalnego partnera gospodarczego czy finansowego. Istniała duża dowolność w zakresie zatrudniania jako ochroniarzy i prywatnych detektywów osób całkowicie nieprzeszkolonych $\mathrm{w}$ aspekcie ich przydatności do zawodu, ponadto często przypadkowych, nie mających kwalifikacji, a nawet wiedzy odnośnie tego, co będzie obszarem ich pracy. Również w tym wypadku sytuacja taka prowokowała wiele nadużyć, nieuprawnionej ingerencji w dobra osobiste obywateli, tworzenia klimatu sprzyjającego korupcji na styku z aparatem urzędniczym czy administracyjnym, a nawet popełniania przestępstw sensu stricto ${ }^{7}$.

\section{Konsekwencje prywatyzacji zadań publicznych}

Co do wysuwanych wątpliwości w zakresie efektywności procesu prywatyzacji uznać należy niewątpliwą słuszność funkcjonariuszy Policji i innych podmiotów odpowiedzialnych ustawowo za zapewnienie bezpieczeństwa wewnętrznego $\mathrm{w}$ państwie, wyrażających obawy dotyczące zarówno kwestii należytej interpretacji szczegóło-

7 S. Tokarz, Firmy detektywistyczne i ochroniarskie w Polsce ..., s. 347-349, S. Pieprzny, Policja - organizacja i funkcjonowanie, Warszawa 2011, ss. 71, 75-76. 
wych przepisów prawnych, jak i ich praktycznej implementacji przez pracowników firm ochroniarskich i detektywistycznych. Wynika to $\mathrm{z}$ faktu, iż bezpieczeństwo publiczne jest obszarem na tyle newralgicznym, iż nawet pozornie niewielki błąd przy interpretacji treści aktu normatywnego regulującego daną kwestię, może wywołać szereg niepożądanych wzorców zachowań firm ochroniarskich i detektywistycznych, a tym samym stanowić pole do nadużyć. Swoista tendencja do obchodzenia bądź też nadinterpretacji prawa przez pracowników ochrony wynika również z faktu, iż trudno do ich pracy odnieść kategorię „służby” dla dobra społeczeństwa i państwa, która z kolei w odniesieniu do policjantów może działać mitygująco jeśli chodzi o możliwość nadużywania prawa. Należy wskazać, iż uregulowanie i ustawowe dookreślenie wymogu znajomości procedury postępowania w określonych sytuacjach, a także uprawnień przysługujących pracowników ochrony osób i mienia oraz firm detektywistycznych, stanowiłoby fundamentalne kryterium efektywności i praworządności ich działania.

Aby jednak wskazać przede wszystkim na zagrożenie płynące obecnie z usług świadczonych przez te podmioty, szanse bowiem wydają się oczywiste, choć i one zostaną przeanalizowane, należy wyróżnić podstawowe zasady działania firm ochroniarskich i detektywistycznych. Tak więc, zakres udziału firm ochroniarskich w dziedzinie bezpieczeństwa i porządku publicznego uzależniony jest od ich rodzaju. Wśród nich wyróżnia się bowiem służby zobligowane do posiadania koncesji i działające $\mathrm{w}$ takim przypadku jako specjalistyczne uzbrojone formacje ochronne oraz takie, które mogą działać jedynie w oparciu o zezwolenie wydane przez komendanta wojewódzkiego Policji. Kryterium różnicującym działalność koncesjonowaną od tej prowadzonej na zasadzie zezwolenia jest obowiązkowa ochrona obszarów, obiektów i urządzeń wpisanych do ewidencji prowadzonej przez wojewodę. Z kolei samo nazewnictwo „ochrona osób i mienia” wskazuje na konieczność wyartykułowania przez ustawodawcę, iż ochrona osób powinna zmierzać do zapewnienia bezpieczeństwa 
życia, zdrowia i nietykalności osobistej, natomiast ochrona mienia ma na celu zapobieganie przestępstwom i wykroczeniom przeciwko mieniu, jak też przeciwdziałanie powstaniu szkody wynikającej z tych zdarzeń oraz niedopuszczenia do wstępu osób nieuprawnionych na teren chroniony. Ustawa przewiduje ponadto dwie formy ochrony, a mianowicie bezpośrednią ochronę fizyczną i zabezpieczenie techniczne. Do wykonywania zadań z zakresu ochrony osób i mienia uprawnione są trzy grupy pracowników, a mianowicie osoby posiadające licencję pracownika ochrony fizycznej i licencję pracownika zabezpieczenia technicznego oraz pracownicy ochrony, mogący wykonywać zadania ochronne bez posiadania licencji. Z kolei warunkiem uzyskania licencji, do wydania której właściwym organem jest komendant wojewódzki Policji, jest, poza warunkami formalnymi określonymi w ustawie, zdanie egzaminu przed właściwą komisją. Warte odnotowania wydają się też środki prawne przyznane pracownikom ochrony, które można podzielić na podstawowe i pomocnicze. Do środków podstawowych należy ustalenie uprawnień do przebywania osób na obszarach lub w obiektach chronionych, legitymowanie w celu ustalenia tożsamości, wezwanie osób do opuszczenia obszaru lub obiektu w przypadku stwierdzenia braku uprawnień do przebywania na terenie chronionym bądź stwierdzenia zakłócenia porządku publicznego, ujęcie osób stwarzających w sposób oczywisty bezpośrednie zagrożenie dla życia bądź zdrowia ludzkiego, a także chronionego mienia oraz niezwłoczne oddanie tych osób Policji. Celem skutecznego użycia wskazanych środków możliwe jest zastosowanie środków przymusu bezpośredniego, mieszczących się w drugiej grupie środków prawnych, o charakterze pomocniczym. Środki przymusu bezpośredniego mogą być stosowane $\mathrm{w}$ wypadku zagrożenia dóbr powierzonych ochronie bądź też odparcia ataku na pracownika ochrony, jednakże tylko wobec osób uniemożliwiających wykonywanie przez pracownika zadań wynikających z ustawy. Do środków tych należą: siła fizyczna w postaci chwytów obezwładniających oraz podobnych technik obrony, kajdanki, pałki obronne wielofunkcyjne, psy 
obronne, paralizatory elektryczne, broń gazowa i ręczne miotacze gazu. Ponadto wskazuje się, iż wybór określonego środka uzależniony jest od wymogów konkretnej sytuacji, w której nie nastąpi podporządkowanie się wezwaniu do określonego zachowania8.

Katalog środków prawnych, zwłaszcza pomocniczych, przysługujących pracownikom ochrony osób i mienia może wzbudzać poważne wątpliwości i zastrzeżenia co do możliwości nadużyć wynikających $\mathrm{z}$ tak rozległych uprawnień przyznanych osobom niebędącym funkcjonariuszami służb policyjnych. Otóż możliwość użycia zwłaszcza broni gazowej, paralizatorów elektrycznych czy broni gazowej i ręcznych miotaczy gazu i to w dodatku w sposób poniekąd uznaniowy, wynikający z własnej interpretacji sytuacji implikującej konieczność ich użycia, a zatem możliwe, iż niekiedy w sposób niezgodny ze stanem faktycznym, wzbudza słuszne obawy osób zajmujących się tą problematyką. Dodatkowo jeśli weźmie się pod uwagę fakt, iż poza wskazanymi środkami przymusu bezpośredniego istnieje możliwość użycia broni palnej, trudno nie zgodzić się z opinią m. in. Stefana Tokarza, który wprawdzie formułował swoje zastrzeżenia przed wejściem w życie Ustawy o ochronie osób i mienia, ale pomimo tego nie straciły one wiele na swej aktualności. Stwierdza on mianowicie, iż:

ustawodawca nie powinien rozszerzać (...) uprawnień do stosowania środków przymusu bezpośredniego ponad uprawnienia ogólnoobywatelskie, wynikajace z prawa do obrony koniecznej. Problem ten nie powinien być rozwiazywany środkami siłowymi, ale raczej przez właściwy dobór kadr do zawodu, ich wszechstronne szkolenie oraz wyposażenie techniczne. Broń winna służyć agentowi ochrony tylko do odparcia bezwzględnego, bezpośredniego i rzeczywistego zamachu na dobro najwyższe, tj. życie i zdrowie. Obrona żadnej innej wartości chronionej przez agenta nie powinna być uznana za powód do użycia przeciwko napastnikowi broni palnej, zwłaszcza, że nierozważne jej użycie, może narazić na niebezpieczeństwo rów-

8 S. Pieprzny, Prywatyzacja zadań Policji, [w:] S. Pikulski, W. Pływaczewski, J. Dobkowski (red.), Przemiany doktrynalne i systemowe prawa publicznego, s. 268-269. 
nież osoby postronne. Agent ochrony winien być tak wyszkolony, by nie dał się zaskoczyć napastnikowi, ale jeśli do napadu już dojdzie i zaistnieje niebezpieczeństwo dla życia i zdrowia jego i osób trzecich, powinien on umieć zachować się odpowiedzialnie9.

Krytyczne uwagi tego autora można dostrzec również odnośnie do ustawy o ochronie osób i mienia. I choć stwierdza on, że to uregulowanie prawne było niezbędne i pożądane z punktu widzenia problematyki bezpieczeństwa wewnętrznego państwa, to jednak wskazuje na pewne jej mankamenty. Ustawa bowiem znacznie rozszerzyła uprawnienia pracownika ochrony do stosowania środków przymusu bezpośredniego, które odtąd mogą wykraczać poza uprawnienia ogólnoobywatelskie, wynikające z obrony koniecznej, stanu wyższej konieczności i prawa ujęcia sprawcy przestępstwa na gorącym uczynku lub w bezpośrednim pościgu. Zastrzeżenia wzbudza również art. 36, w którym mowa o użyciu broni palnej przeciwko osobie, która na wezwanie pracownika ochrony nie odrzuci natychmiast broni lub innego niebezpiecznego narzędzia. $Z$ tego wynika, iż niezwykle niebezpieczną sytuacją może okazać się ta, w której nie następuje jeszcze bezpośrednie niebezpieczeństwo, a pojawia się jedynie groźba jego zaistnienia. Nie do końca adekwatny do mogących zaistnieć realnych zagrożeń wymuszających konieczność użycia broni palnej jest natomiast ust. 2 pkt. 4 tego artykułu, który stanowi, iż zakazuje się użycia broni palnej wobec niektórych osób, m. in. w podeszłym wieku, kobiet ciężarnych, nieletnich (do lat 13). Być może jednak w stosunku do takich właśnie osób należałoby zachować szczególną czujność, zwłaszcza że celowo mogą one zechcieć wykorzystać swoją „uprzywilejowaną" pozycjęi10.

Podobnie jak ustawa o ochronie osób i mienia, tak i regulacje prawne dotyczące działalności firm detektywistycznych również mogą wzbudzać kontrowersje. Ustawa o usługach detektywistycznych uchwalona została bowiem dopiero 6 lipca 2001 r. A zatem do tej po-

\footnotetext{
9 S. Tokarz, Firmy detektywistyczne i ochroniarskie w Polsce..., s. 349-350.

10 Tamże, s. 354.
} 
ry podstawą działań detektywów mogły być tylko wzorce powstałe w ich wyobraźni, bazujące na metodach pozaprawnych, nie podlegających kontroli ani ograniczeniom. Taki stan rzeczy musiał istotnie powodować konflikty z policją i innymi służbami odpowiedzialnymi za stan bezpieczeństwa państwa, ponadto mógł także stwarzać pole do oczywistych nadużyć. Po uchwaleniu ustawy określone zostały zasady wykonywania działalności gospodarczej w zakresie usług detektywistycznych, wyróżniono prawa i obowiązki detektywów oraz zasady i tryb nabywania uprawnień do wykonywania tego rodzaju usług. Istotne z punktu widzenia przepisów ustawy jest zdefiniowanie usług detektywistycznych , do których należą czynności polegające na uzyskiwaniu, przetwarzaniu i przekazywaniu informacji o osobach, przedmiotach, zdarzeniach, a w szczególności:

$w$ sprawach wynikających ze stosunków prawnych dotyczq̨cych osób fizycznych; w sprawach wynikających ze stosunków gospodarczych dotyczq̨cych wykonania zobowiq̨zań majątkowych, zdolności płatniczych lub wiarygodności $w$ tych stosunkach, bezprawnego wykorzystywania nazw handlowych lub znaków towarowych, nieuczciwej konkurencji lub ujawnienia wiadomości stanowiacych tajemnice przedsiębiorstwa lub tajemnice handlowq; sprawdzenie wiarygodności informacji dotyczących szkód zgłaszanych zakładom ubezpieczeniowym; poszukiwanie osób zaginionych lub ukrywajacych sie; poszukiwanie mienia, zbieranie informacji $w$ sprawie, $w$ której toczy się postępowanie karne, postępowanie w sprawach o przestępstwa skarbowe i wykroczenia skarbowe i inne, jeśli w toku postępowania można zastosować przepisy prawa karnego ${ }^{11}$.

Warto zwrócić także uwagę na brak wskazania katalogu środków i metod, które może stosować detektyw w czasie wykonywania czynności, przy jednoczesnym wyszczególnieniu tego, czego detektywowi robić nie wolno. A zatem zgodnie $\mathrm{z}$ art. 7 wykonując usługi detektywistyczne, nie może on stosować środków technicznych oraz metod i czynności operacyjno - rozpoznawczych, zastrzeżonych dla upo-

11 S. Pieprzny, Policja - organizacja i funkcjonowanie..., s. 76. 
ważnionych organów na mocy odrębnych przepisów ${ }^{12}$. Tego rodzaju uregulowanie prawne wydaje się poważnym mankamentem tej ustawy, ponieważ sprawia on, iż przepisy zawarte w tym akcie prawnym pozostają $\mathrm{w}$ rażącej sprzeczności $\mathrm{z}$ szerokim katalogiem sytuacji i spraw, co do których zastosowanie znajdują usługi detektywistyczne, zwłaszcza, iż katalog ten nie ma charakteru enumeratywnego, o czym świadczy zwrot „w szczególności”. W tym kontekście słuszne wydają się obawy i sceptyczne nastawienia środowisk detektywistycznych, dowodzących, iż nie można szpiegować w sposób jawny, a taka konieczność wynika wszakże z Ustawy, która nie dopuszcza możliwości wykonywania czynności operacyjno - rozpoznawczych. Stawia to ponadto pod znakiem zapytania skuteczność i sensowność usług detektywistycznych, które niejako a priori, winny być prowadzone w sposób niejawny. Na tle tego typu ograniczeń w stosunku do detektywów co najmniej nie do końca zrozumiałe wydaje się przyznanie $w$ gruncie rzeczy nadmiernie szerokich uprawnień pracownikom firm ochroniarskich.

Konkludując, można zatem stwierdzić, iż prywatyzacja zadań Policji $\mathrm{w}$ aspekcie zaangażowania podmiotów niepublicznych w zapewnienie bezpieczeństwa wewnętrznego, w omawianym przypadku firm ochroniarskich i detektywistycznych, pociąga za sobą zarówno pozytywne przewartościowania w zakresie całokształtu zadań Policji, jak i cały szereg zagrożeń i zjawisk patologicznych, mogących wyniknąć zawsze, ilekroć monopol państwa w jakiejś ważnej społecznie dziedzinie zostaje naruszony. Jeden z badaczy tego zagadnienia, Stanisław Pieprzny, stwierdza, iż istnieje wręcz konieczność prywatyzacji zadań Policji na rzecz podmiotów niepublicznych. Argumentuje on swoje stanowisko, wskazując, iż w ostatnim czasie zaobserwować można coraz większe zainteresowanie usługami firm ochrony osób i mienia, zaś czynnikiem wpływającym na rozwój prywatnych firm ochrony jest m. in. brak możliwości zapewnienia obywatelom pełnej ochrony przed przestępstwami przez administrację państwową i samorządo-

12 Tamże, s. 77. 
wą (notabene pozapaństwowe podmioty ochrony osób i mienia zatrudniają ok. 250 tys. pracowników, a zatem dwa razy tyle co Policja). Ponadto prywatyzacja gospodarki i dysponowanie dużą ilością dóbr materialnych przez podmioty prywatne wymusza konieczność dbałości tych podmiotów o prawidłowe zabezpieczenie ich przed zamachami przestępczymi. Czynnikiem przemawiającym za prywatyzacją, wskazywanym przez Pieprznego, jest skoncentrowanie się przez Policję na tych obszarach zagrożenia bezpieczeństwa i porządku publicznego, które są najbardziej dotkliwe dla społeczeństwa, przy czym w szczególności chodzi tu o miejsca publiczne, zaś taką sytuację umożliwiałoby przejmowanie części zadań Policji właśnie przez policje prywatne. Na korzyści płynące z działalności prywatnych firm ochroniarskich i detektywistycznych miałaby wskazywać także możliwość wzmocnienia osobowego służby kryminalnej i prewencyjnej, pozytywne doświadczenia innych państw, w których także funkcjonują prywatne firmy ochrony oraz spadek liczby przestępstw przeciwko mieniu ${ }^{13}$.

Wszystko to niewątpliwie jest prawdą i słusznie wskazuje się na element „odciążenia” Policji w zakresie zadań związanych z bezpieczeństwem wewnętrznym poprzez częściowe scedowanie odpowiedzialności za nie podmiotom niepublicznym, jednakże opisane argumenty, uwypuklające przede wszystkim pozytywne aspekty prywatyzacji zadań Policji, wskazują raczej na pewien stan modelowy, pożądany z punktu widzenia państwa i społeczeństwa, lecz niekoniecznie istniejący w rzeczywistości. Wątpliwości i obawy, które wzbudzać może przede wszystkim działalność firm ochroniarskich, w mniejszym stopniu detektywistycznych ze względu na znacznie zawężony katalog uprawnień i możliwości działania przysługujących detektywom, wynikają z kilku powodów, które można rozpatrywać na dwu płaszczyznach. Pierwsza z nich odnosi się do relacji między funkcjonariuszami służb policyjnych a pracownikami ochrony, druga natomiast dotyczy zapatrywań i realnych potrzeb obywateli $\mathrm{w}$ aspekcie

13 Tamże, s. 78-79. 
zapewnienia bezpieczeństwa. Otóż pomimo tego, iż ustawa o ochronie osób i mienia określa m. in. obszary, obiekty i urządzenia podlegające obowiązkowej ochronie, zasady tworzenia i funkcjonowania wewnętrznych firm ochrony, zasady prowadzenia działalności gospodarczej w zakresie usług ochrony osób i mienia, a także wskazuje na wymagane kwalifikacje i uprawnienia pracowników ochrony oraz nadzór nad funkcjonowaniem służb tej ochrony, to jednak wydaje się, iż większą rolę niż obwarowania prawne odgrywa czynnik ludzki, który na tle relacji Policji i firm ochroniarskich może powodować rywalizację obu tych podmiotów. Zważywszy na fakt, iż firmy ochrony osób i mienia zatrudniają dwukrotnie więcej pracowników niż Policja, może dojść do sytuacji, w której zdeprecjonowany zostanie autorytet funkcjonariusza Policji, a celowość istnienia tej służby może ostatecznie zostać w ogóle podana w wątpliwość, skoro tak ważka społecznie dziedzina, jak zapewnienie bezpieczeństwa wewnętrznego może być realizowana przez inne podmioty. Tym bardziej więc można sobie wyobrazić sytuację, iż w przyszłości także inne obszary życia w sferze publicznej zostaną sprywatyzowane, co niekoniecznie pociągnie za sobą wyłącznie same korzyści. Ponadto służba w Policji stanowi swego rodzaju permanentne zdobywanie doświadczenia zawodowego przez cały okres trwania służby, podczas gdy pracownik ochrony po spełnieniu wymogów formalnych i uzyskaniu licencji zyskuje cały szereg rozległych środków prawnych, które już same w sobie budzą poważne zastrzeżenia natury etyczno-moralnej. Innego rodzaju jest również nastawienie funkcjonariusza, który swoją służbę w Policji traktuje raczej jako powołanie, a przynajmniej takie można odnieść wrażenie na podstawie obserwacji działalności niektórych policjantów, podczas gdy dla pracownika ochrony zatrudnienie w prywatnej firmie ochroniarskiej ma najczęściej charakter pracy zarobkowej. 


\section{Kwestia akceptacji społecznej dla prywatyzacji zadań publicznych}

Z kolei jeśli chodzi o aspekt obywatelski w kontekście funkcjonowania prywatnych firm ochroniarskich, należy rozważyć czy rzeczywiście istnieje tak rozległe zapotrzebowanie społeczeństwa na usługi świadczone przez tego rodzaju podmioty, czy istotnie ich bardzo duża liczna jest konieczna dla osiągnięcia celu, jaki stanowi zapewnienie bezpieczeństwa wewnętrznego. Prywatne firmy ochrony powinny w założeniu sprzyjać ograniczeniu przestępczości przeciwko osobom i mieniu, jednak pytanie, czy rzeczywiście tak jest, wciąż pozostaje aktualne. Dla stwierdzenia ich skuteczności nie wydaje się wystarczająca opinia, wysuwana przez entuzjastów prywatyzacji zadań Policji, iż dzięki temu procesowi zmniejsza się skala przestępstw skierowanych przeciwko mieniu. Zjawisko ograniczenia rozmiarów przestępczości stanowi bowiem zbyt złożone zagadnienie, aby poddawać je tego rodzaju uproszczeniom. Poza tym ustawa o ochronie osób i mienia została uchwalona celem uregulowania przede wszystkim pewnych formalnych kwestii związanych $\mathrm{z}$ funkcjonowaniem systemu ochrony osób i mienia wraz z wymogami wobec osób mających tę ochronę sprawować. Stanowiła ona odpowiedź na narastającą przestępczość w tej materii, jednak decyzja, choć niewątpliwie podyktowana troską o społeczeństwo, została podjęta odgórnie Doniosłość i znaczenie prywatyzacji zadań Policji na rzecz podmiotów niepublicznych powinna być więc poprzedzona konsultacjami ze społeczeństwem, rzetelnym przeanalizowaniem zapotrzebowania na te usługi świadczone przez tego rodzaju firmy zamiast wyłącznie przez Policję. Co więcej, wsłuchiwanie się w opinię społeczną na ten temat powinno odbywać się cyklicznie, a nie tylko jednorazowo, tym bardziej że ustawa nie przewiduje środków ochrony przysługujących obywatelom w przypadku ewidentnych nadużyć ze strony pracowników firm ochroniarskich. Warto pochylić się również nad kwestią relacji między obywatelami a Policją, ponieważ ma to też pośrednie znaczenie dla akceptacji społecznej firm ochroniarskich wyposażo- 
nych w szereg uprawnień ściśle policyjnych. Otóż wizerunek Policji w oczach społeczeństwa wciąż nie jest zadowalający. Policja, pomimo nieustannych zabiegów na rzecz ocieplenia wizerunku, nadal dla większości obywateli pozostaje organizacją opresyjną. Tym bardziej więc przekazanie uprawnień w zakresie bezpieczeństwa wewnętrznego podmiotom niepublicznym wywoływać może konsternację społeczną i jawne niezadowolenie, a ostatecznie dowodzić nieudolności Policji zmuszonej do współpracy z podmiotami prywatnymi. Z pewnością tego rodzaju wyobrażenia funkcjonujące w świadomości społecznej nie przysparzają ani Policji, ani tym bardziej firmom ochroniarskim popularności. Stan ten może być, co więcej, pogłębiony wraz ze wzrostem liczbowym prywatnych firm ochrony osób i mienia. Tak więc ocena realnej potrzeby istnienia na tak szeroką skalę firm ochrony powinna być regularnie aktualizowana.

\section{Literatura:}

Administracja i prawo administracyjne u progu trzeciego tysiqclecia. Materiały konferencji naukowej katedr prawa i postępowania administracyjnego, Wydawnictwo Uniwersytetu Łódzkiego, Łódź 2000.

Widacki J., Czapska J. (red.), Bezpieczny obywatel - bezpieczne państwo, Wydawnictwo Katolickiego Uniwersytetu Lubelskiego, Lublin 1998.

Biernat S., Prywatyzacja zadań publicznych. Problematyka prawna, Wydawnictwo Naukowe PWN, Warszawa-Kraków 1994.

Pieprzny S., Policja - organizacja i funkcjonowanie, Wyd. Lex a Wolters Kluwer business, Warszawa 2011.

Pikulski S., Pływaczewski W., Dobkowski J. (red.), Przemiany doktrynalne i systemowe prawa publicznego, Wyd. Zakład Poligraficzny Uniwersytetu Warmińsko-Mazurskiego, Olsztyn 2002. 